\title{
Progress Report of Cyber Society v1.0 Development as a Learning Media for Indonesian Society to Support EFA
}

\author{
https://doi.org/10.3991/ijep.v10i4.13085 \\ Nuur Wachid Abdul Majid ${ }^{\square}$, Syifaul Fuada \\ Universitas Pendidikan Indonesia, Bandung, Indonesia \\ nuurwachideupi . edu \\ Muhammad Khoirul Fajri \\ Teknik Informatika, STMIK AKAKOM Yogyakarta, Yogyakarta, Indonesia \\ Muhammad Nurtanto \\ Universitas Sultan Ageng Tirtayasa, Banten, Indonesia \\ Robby Akbar \\ Indonesia University of Education, Bandung, Indonesia
}

\begin{abstract}
In this paper, we present the progress in developing the Cyber Society (CS) v.1.0, which is a prototype of intelligent learning concepts that can be employed in the $21^{\text {st }}$ century and become the future-proof technology. This paper is a continuation of the previous work that discussed there a high-possible to develop specific e-learning for Indonesian society to support Education for All (EFA); therefore, this work will focus on the realization of our idea. It will start from "analysis" to the "evaluation" steps. The discussion of this paper comprises of (1) analyzing the needs and minimum requirements of the CS prototype; (2) designing; (3) developing; and (4) evaluating the CS prototype. Once the CS has been developed, then, we evaluated the CS website v1.0 using the black-box method; it shows that the system buttons can be run well as expected. Later, we tested its Usability through the SUS questionnaire that obtained from 50 participants, we got eighty (80) of the mean score. According to the SUS measurement, the feasibility of CS website v1.0 can be categorized as follows: (1) Promoter NPS; (2) Acceptable; (3) Excellent Adjective; and (4) A- Grade. This work has usefulness in developing modern teaching \& learning patterns. Moreover, it is expected to be a medium of online-based learning with real-time concepts without any limitations on time, age, and distance. Our system can be used as a reference model in developing future technology-based learning media.
\end{abstract}

Keywords-Intelligent learning, Cyber society, MOOCs

\section{Introduction}

Currently, we are in an era full of communication and information technology. Advances in technology have provided a huge source of information and communication 
from what humans have [1][2]. Looking at the portrait of education in this era emphasizes the concept of transfer of knowledge rather than character education [3]. In several continents such as Europe, many universities no longer carry out teaching and learning in class and are replaced by online learning. This online learning is also one of the smart city programs that are being launched by each local government to tackle problems leading to advanced development [4]. In addition to online learning, universities in Europe also complete the teaching and learning process with several additional models, such as Project-based learning. Activities that applied to students are so exciting; students are asked to solve problems in the field with the help of technology so that countries in Europe are very familiar with technology-based learning [5][6].

This condition seems different from Indonesia. Ministry of Research, Technology, and Higher Education, Mohamad Natsir said that Indonesia was still weak in the fields of higher education and training, science and technology readiness, innovation and business sophistication so that technology-based learning could not be applied optimally [7]. This has an impact on the quality of education and Indonesia's readiness to face the industrial revolution era 4.0. The Indonesian state ranks in the middle of ASEAN in preparation for the Industrial Revolution. The aspect of Indonesia's technological readiness is still very weak, and its value is 3.9 [8]. This value is below the countries of Malaysia, Thailand, Singapore and Brunei Darussalam. This shows that Indonesia still needs to improve technology development through the support of universities and research institutions. Based on these data, the Indonesian government needs to improve the competitiveness of graduates of the Indonesian people to increase.

Strategic efforts that can be done by the Ministry of Research, Technology, and Higher Education is to improve programs and services that use more online technology. In the era, of industrial technology 4.0, Indonesia needs to change the perspective of the concept of education that is directed at digitalization and computerization. One of the changes made is the way of teaching and learning media used. In this era, it is possible for learning interactions that do not recognize space, time and learning can be done without face to face. This pattern of education thus refers to the era of the industrial revolution 4.0, which utilizes technology during the learning process known as cyberspace [9]. Herefore, it is necessary to improve quality in the realm of infrastructure and teaching staff for ICT competencies as essential education competencies in the $21^{\text {st }}$ century.

E-Learning has experienced massive developments this year; it is a form of learning model that is facilitated and supported by the use of information technology and communication. E-Learning is a new form of pedagogy for learning in the $21^{\text {st }}$ century; it is an e-learning instructional designer, facilitator of interaction, and subject matter experts [10]. This means that e-learning is a new form of pedagogy for learning in the $21^{\text {st }}$ century [11][12]. In this case, the teacher acts as a designer of e-learning, interaction facilitators, and subject matter experts.

E-learning has characteristics: 1) have content that is relevant to the learning objectives; 2) use instructional methods, such as presenting examples and exercises to improve learning; 3) use media elements such as words and pictures to convey learning material; 4) enables direct learning centered on the teacher (synchronous e-learning) or 
designed for independent learning; 5) build understanding and skills related to learning objectives both individually or improve group learning performance [13].

Making E-Learning can be started from the concept of blended learning to intelligent learning that is being developed in the 21 st century. The concept of intelligent learning will increasingly boom starting in 2020 with a lot of communication through the internet of things (IoT) and in combination with artificial intelligence [14] [15]. Besides containing the presentation of E-Learning material, it should also be made with an attractive and communicative design [16][17].

The CS is an E-Learning learning media with the concept of intelligent learning and becomes future-proof technology. At this stage, the concept of the CS applies the Massive Open Online Courses (MOOCs) model. MOOCs will become a learning technology that continues to develop in Indonesia given the large population and efforts to increase society access to training and education [18][19][20]. Prior work states that student learning outcomes after using the learning media is increased [21].

This paper is a follow up to the literature study that has been done by previous work as in [15]. Hence, the purpose of this study is to describe the design, develop, and evaluate the CS website for Indonesia society.

\section{$2 \quad$ Method}

The development of this application was based on the Research and Development (R\&D) method. It was expected to produce an e-learning prototype as part of technology-enabled learning. In this work, the software development uses the Software Life Cycle Development (SDLC) model. This model was used for the waterfall model with five stages of development, namely : (1) requirements analysis and definition; (2) system and software design; (3) implementation and unit testing; (4) integration and system testing; and (5) operation and maintenance [22].

The usability testing involved the sample of 50 participants was obtained randomly. The participants of this study were average 24 years old, where 22 of them are male and 28 are female. This work adopted the System Usability Scale (SUS) to investigate the usability of the CS v1.0. The SUS is provided to evaluate of their product and user interface.

\section{$3 \quad$ Results and Analysis}

The development of interactive learning media has an impact on users, in particular, increasing student competence. This concept was adopted to help the society improve its competence and support education for all movements. The prototype development of CS v1.0 has become the primary foundation for promoting the distribution of education in Indonesia. E-learning is expected to help the government deliver education to the public. 


\subsection{Requirement analysis}

An analysis of the requirements is the collection of requirements needed to develop a complete application. In the analysis phase, data flow diagrams (DFD) and case activity diagrams are using. This DFD is dividing into 2, namely DFD level 0 and level 1 , which at level 1 is a detailed description of the flow diagram conceptualized in the flow diagram level 0. At this level 0 DFD, the CS Website System has two activities: admin and visitor. Admin functions for adding, updating, deleting information that will be displayed on the web. Visitors to the website may have access to the information presented by the Admin.

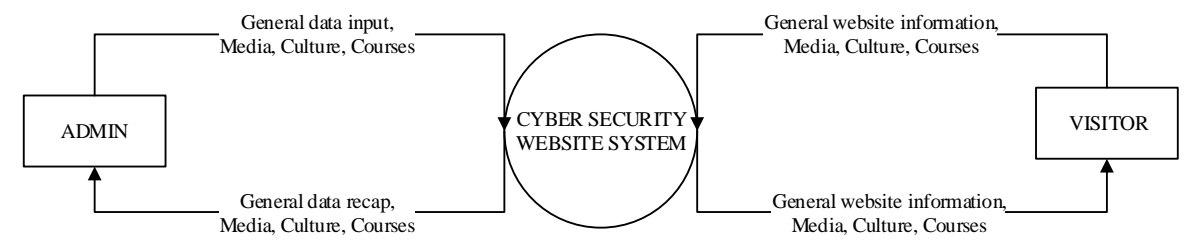

Fig. 1. DFD level 0

At DFD level 1, it is an activity in detail in both activities as a description of DFD level 0. In Fig. 2 described there are 8 activities, namely: general data input, media data input, culture data input, course data input, access CS landing page, access CS media page, access CS culture page, and access CS course pages.

Table 1 explains the menu functions available on the website. The menus are connecting to the database. So if the administrator makes changes to the site, the contents will change automatically according to the changes made by the admin via the admin page. Besides, the analysis phase is also carried out using a use case diagram.

Table 1. Features on the CS menu

\begin{tabular}{|l|l|l|}
\hline \multicolumn{1}{|c|}{ ID } & Menu Featured & \multicolumn{1}{c|}{ Description } \\
\hline H1 & Home & On the home menu, users can see the total content on the main web page \\
\hline A1 & About & A full description of about the website \\
\hline T1 & Team & Describes the team that developed the website \\
\hline C1 & Culture & described information about cultural diversity in Indonesia \\
\hline C2 & Course & Contains courses that can be accessed by users \\
\hline M1 & Media & Contains tutorial videos that can help users master the fields conveyed \\
\hline C3 & Contact & Users can contact the admin via a contact form. \\
\hline
\end{tabular}




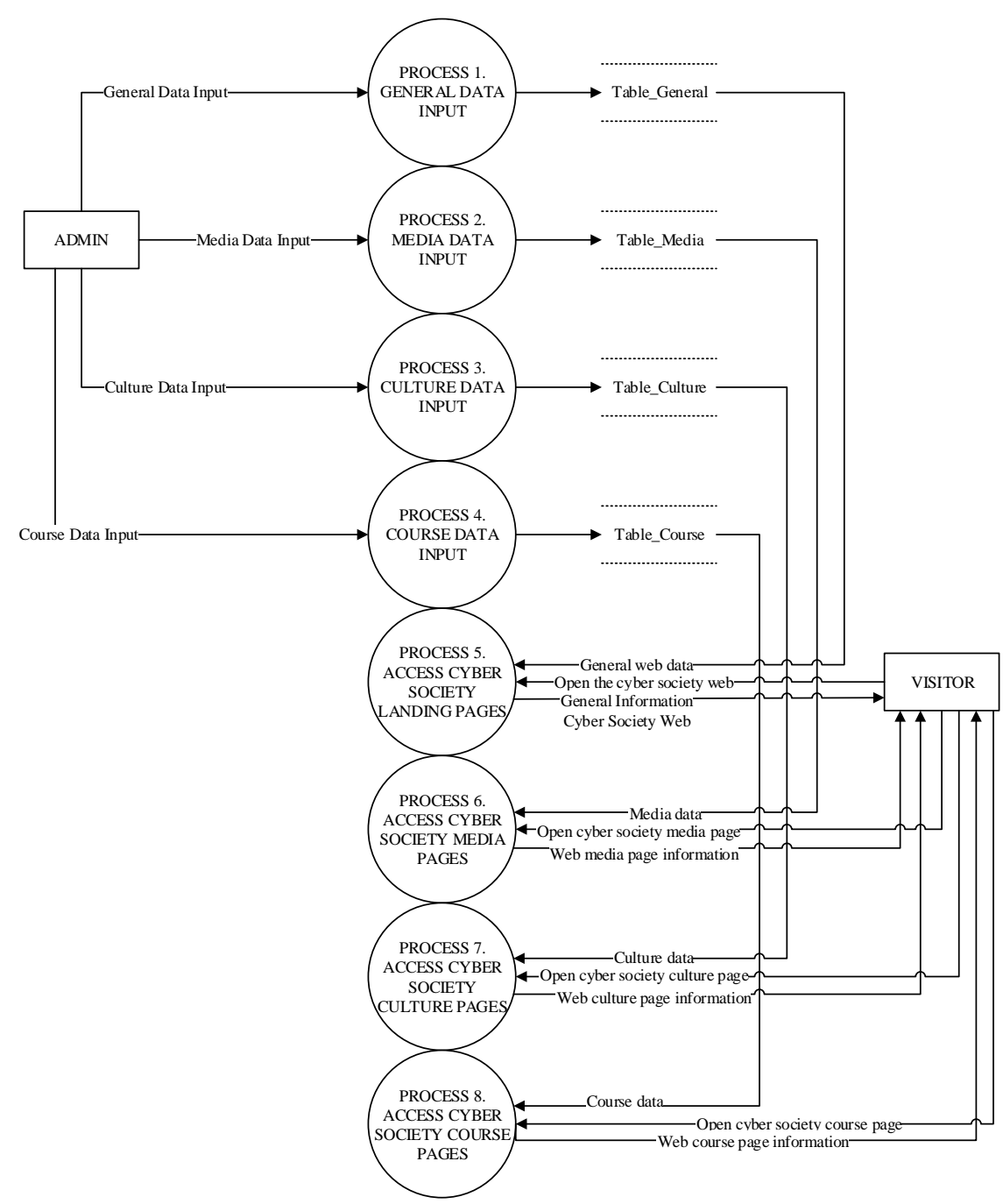

Fig. 2. DFD level 1 


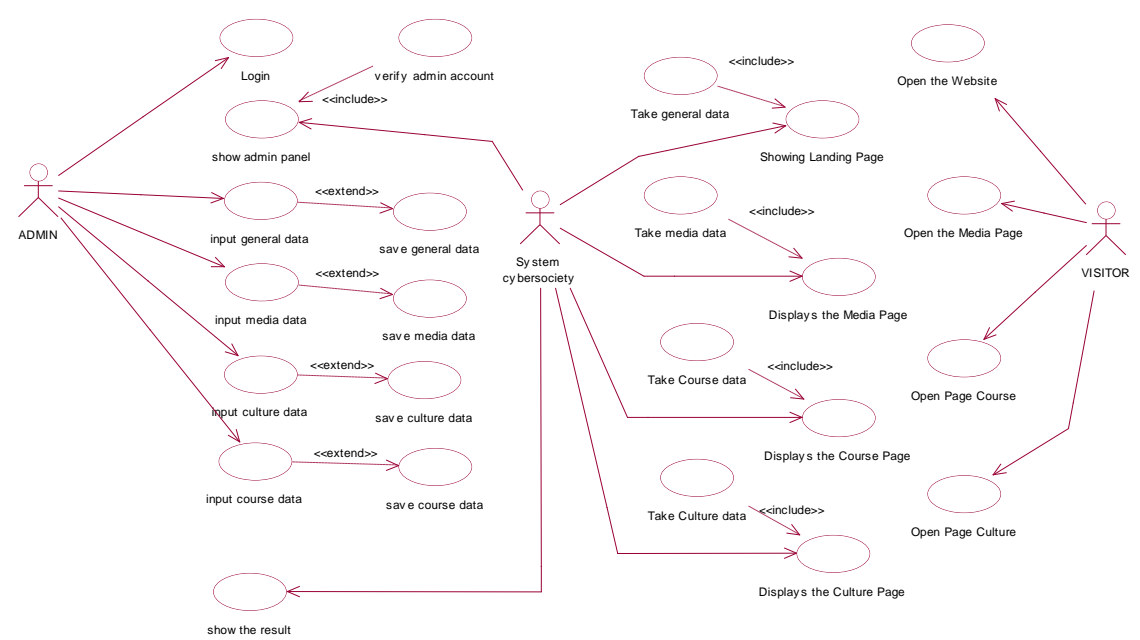

Fig. 3. Use Case diagram

\subsection{Software design}

At this stage, the design of storyboard software is done as part of a rough design in the production and development of software. Figure 3 shows the appearance of a sitemap for the design of websites. In this rough picture, designers are expected to help create designs that are in line with the sketch. The design is designed to apply the principles of UI / UX, and the website is expected to be responsive.
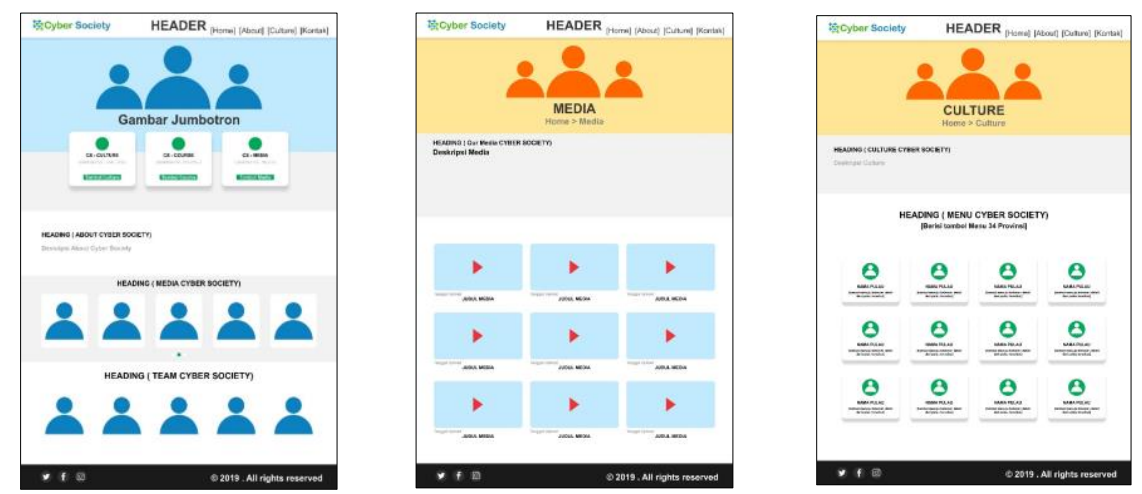

Fig. 4. The CS v.1.0 design

\subsection{Implementation of e-learning in society}

Users can join the website of the CS prototype by opening the browser first. After that, enter the website address https://demo.jogjadev.com/cybersociety/ in such a way 
that the primary screen can appear as in Fig 4. The primary page will contain data about the website, beginning with the website, submenus, and team developers. The submenu of culture includes some data on the province of Indonesia. All data on culture, traditional clothing, dances, arms, languages are discussing in the sub-menu chapter of this culture. In the chapter on culture, all 34 Provinces in Indonesia are shown. The Media segment demonstrates a video tutorial that users can follow. This tutorial is general and is anticipated to enhance user abilities.

An administrator that displays the tasks of adding, editing, and deleting the data displayed on the primary page of the website. The Administrator section has an important role to play in managing the main appearance of the website so that visitors can enjoy the information provided by the Administrator.

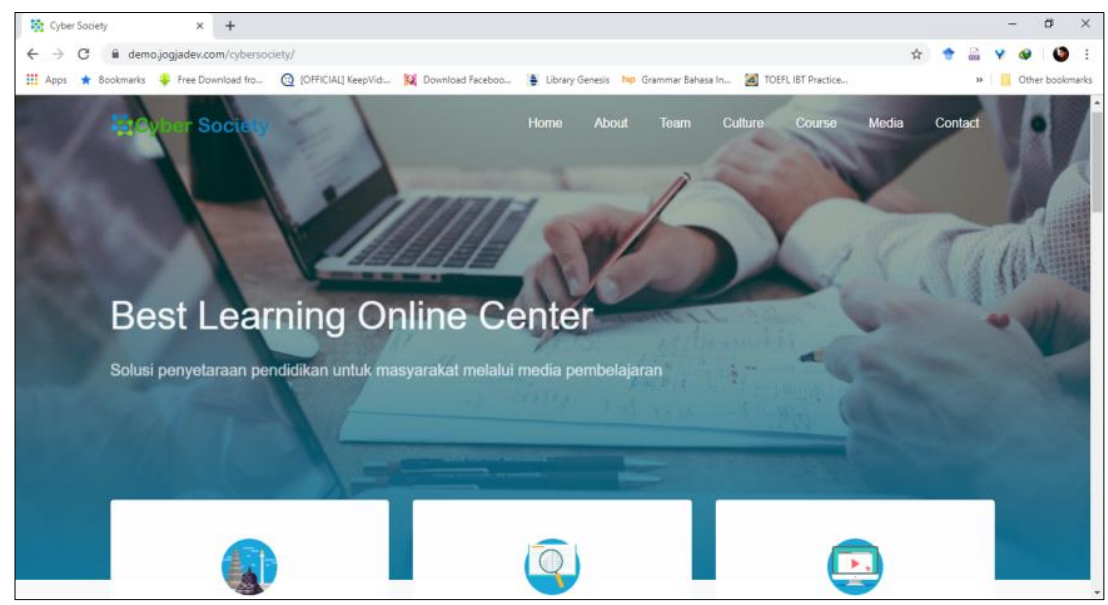

Fig. 5. Front page of the CS

The feature available in this e-learning is to display culture in every province in Indonesia. Each province displays information about several cultures, such as: ceremonies, clothing, languages and traditional weapons. This information can support the community to get to know more about culture in every provinces in Indonesia. This website displays 34 Provinces of Indonesia along with the types of information that can be accessed by users. Figure 5 shows the display for the culture menu that can be accessed by users, it provides several choices of information. 


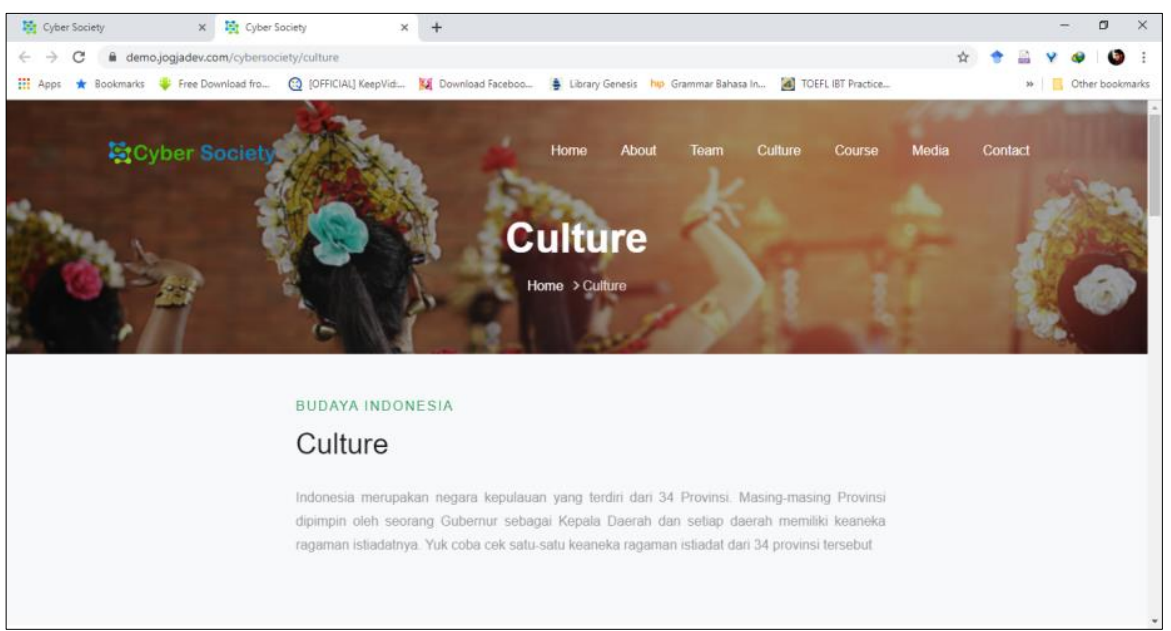

Fig. 6. Menu of Culture to show information of regions in Indonesia

Another submenu display is CS-Media which functions to display videos related to certain discussion tutorials. Users can follow the tutorial shown on the video. Users can access the media for the benefit of formal and informal learning. The media provided consists of several application operation tutorials, a mechanism to make something useful, and other information that can be accessed by all people.

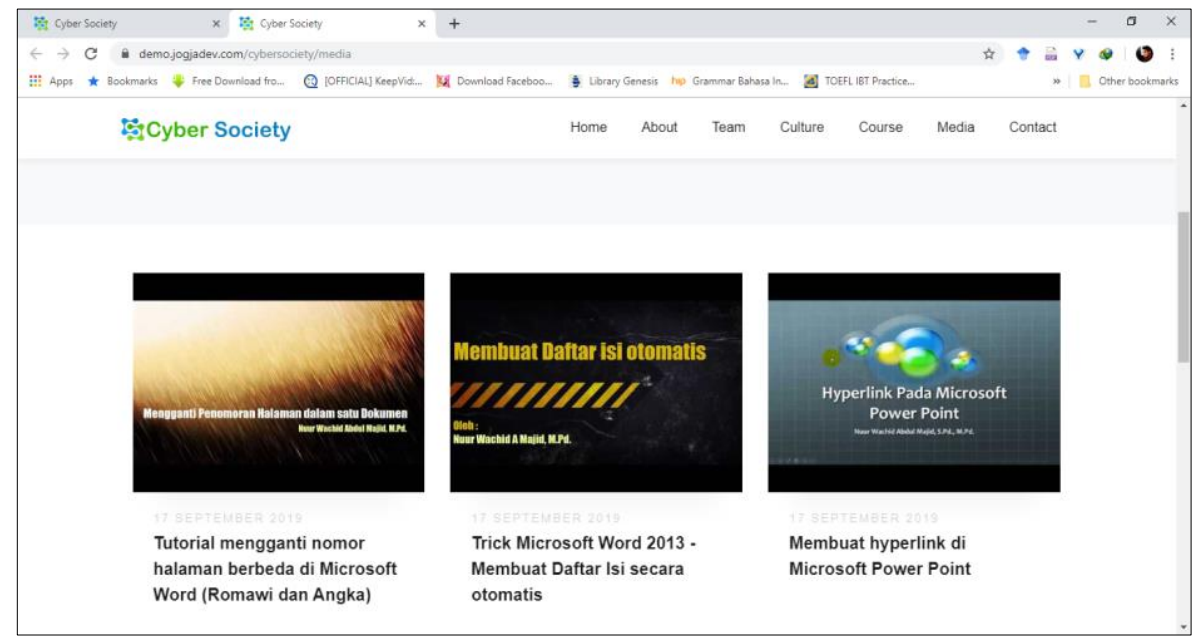

Fig. 7. Menu of Media to show media tutorial

In the course submenu, users can access material that has been uploaded to the Course. On this page some material was uploaded by the experts. The course uses the Moodle platform as a learning management system (LMS) on e-learning systems. 


\subsection{Product testing}

At this point in unit testing using a black-box test. Black box testing is used based on application details such as the appearance of the application, the functions that exist in the application, and the alignment of the function flow with the business process that the customer wants [23]. So, this exam does not look at elements of the source code of the program.

Table 2. Black box testing results on the website the CS v1.0

\begin{tabular}{|l|l|l|}
\hline Menu Featured & \multicolumn{1}{|c|}{ Expected Result } & Test Result \\
\hline Home & $\begin{array}{l}\text { Displays the main page that all information. Every page that clicks } \\
\text { this button will return to the main menu }\end{array}$ & OK \\
\hline About & Displays a page that contains information about the website of CS. & OK \\
\hline Team & Displays a page containing information the team developer & OK \\
\hline Culture & $\begin{array}{l}\text { Displays a page containing a brief history and culture of provinces in } \\
\text { Indonesia }\end{array}$ & OK \\
\hline Course & Displays a page containing the courses in the CS & OK \\
\hline Media & Displays a page containing the learning media & OK \\
\hline Contact & Displays a page containing contact to administrator & OK \\
\hline
\end{tabular}

The result of the black box testing on the CS website v1.0 as shown in Table 2 shows that users open the website and display the main page. Then click the "About" button to show the system response in the center of the page. Similarly, when you press the Team button, the system will react to the display at the bottom of the page. When you press the "Culture" button, the system will respond to show a page culture. The system also responds when you press the Media button, and the media learning video is shown. The last one, if users press the Contact button, will display a contact page.

The e-learning system is also tested on users as part of usability testing. This test uses the SUS questionnaire that consists of 10 phrases that have 5 points Likert scare measuring strength of agreement [24]. Table 3 shows the result dari questionnaire that delivered to 50 users randomly. The users have used the system and then filled out the questionnaire as evaluation material. The result in Table 3 shows that score mean the CS v1.0 is 80 . The score indicates that e-learning is included in the category based on figure 8, namely: (1) NPS: Promoter; (2) Acceptable: Acceptable; (3) Adjective: Excellent; and (4) Grade: A-. 
Table 3. SUS questionnaire result

\begin{tabular}{|c|l|c|c|c|}
\hline \multirow{2}{*}{ No } & \multicolumn{1}{|c|}{ Phrase } & \multicolumn{2}{c|}{ The CS v1.0 } & \multicolumn{1}{|c|}{} \\
\cline { 3 - 4 } & & \multicolumn{1}{|c}{ Score } & Mean & Std.D \\
\hline 1 & I think that I would like to use this feature frequently. & 151 & 3,02 & 0,68 \\
\hline 2 & I found the feature unnecessarily complex. & 167 & 3,34 & 0,592 \\
\hline 3 & I thought the feature was easy to use. & 167 & 3,34 & 0,62 \\
\hline 4 & $\begin{array}{l}\text { I think that I would need the support of a technical person to be } \\
\text { able to use this feature. }\end{array}$ & 157 & 3,14 & 0,49 \\
\hline 5 & $\begin{array}{l}\text { I found the various functions in this feature were well inte- } \\
\text { grated. }\end{array}$ & 172 & 3,44 & 0,57 \\
\hline 6 & I thought there was too much inconsistency in this feature. & 159 & 3,18 & 0,66 \\
\hline 7 & $\begin{array}{l}\text { I would imagine that most people would learn to use this fea- } \\
\text { ture very quickly. }\end{array}$ & 172 & 3,44 & 0,57 \\
\hline 8 & I found the feature very cumbersome to use. & 150 & 3 & 0,53 \\
\hline 9 & I felt very confident using the feature. & 145 & 2,9 & 0,58 \\
\hline 10 & $\begin{array}{l}\text { I needed to learn a lot of things before I could get going with } \\
\text { this feature. }\end{array}$ & 153 & 3,06 & 0,54 \\
\hline
\end{tabular}

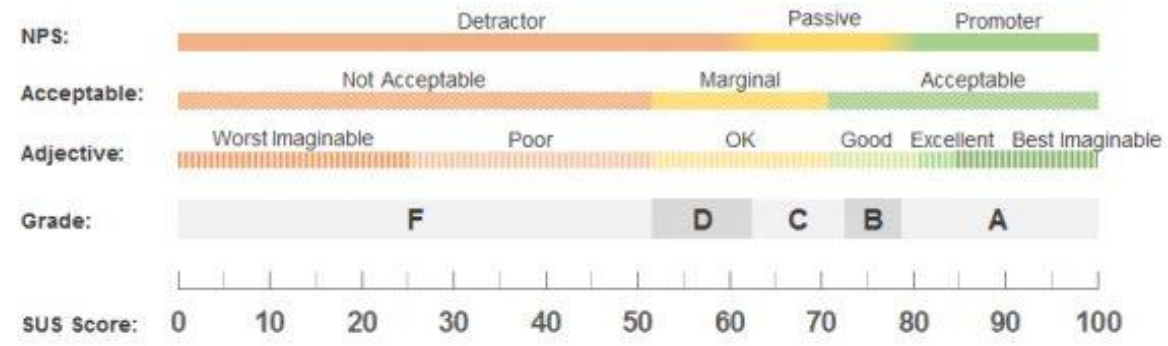

Fig. 8. Grades, adjectives, acceptability, and NPS categories associated with raw SUS scores [25] [26].

The results of this study indicate that the CS system is accepted by the user and belongs to the excellent category. The concept of this system is to make it easy for users to find information related to culture in Indonesia, scientific video tutorials and educational materials that can support the EFA movement as suggested in [15].

\section{Conclusion}

We conclude that (1) the result of the black box testing on the CS website v1.0 shows that the system buttons can be run perfectly; and (2) the CS system still needs to be tested and moved to the next stage. In the testing stage, software quality assurance will be implemented using ISO 9126 models composed of functionality, reliability, usability, effectiveness, upkeep, and portability. Usability testing results show that the mean score of the CS v1.0 is 80 . Therefore, the feasibility of this system is in the category of: NPS: Promoter; (2) Acceptable: Acceptable; (3) Adjective: Excellent; and (4) Grade: A-. 


\section{$5 \quad$ References}

[1] A. Ahmad, "Perkembangan Teknologi Komunikasi Dan Informasi: Akar Revolusi Dan Berbagai Standarnya," Dakwah Tabligh, pp. 137-149, 2012.

[2] A. Hanif, A. F. Siddiqi, and Z. Jalil, "Are Computer Experience and Anxiety Irrelevant? Towards a Simple Model for Adoption of E-Learning Systems," Int. J. Eng. Pedagog., vol. 9, no. 5, pp. 112-125, 2019. https://doi.org/10.3991/ijep.v9i5.11488

[3] A. Y. Anas, "Desa Dan Kota Dalam Potret Pendidikan," in Prosiding Ks: Riset \& Pkm, 2018, pp. 301-444.

[4] N. Faidati and M. Khozin, "Analisa Strategi Pengembangan Kota Pintar (Smart City): Studi Kasus Kota Yogyakarta," J. Ilmu Pemerintah., vol. 3, no. 2, pp. 171-180, 2018. https://doi.org/10.24905/jip.3.2.2018.171-180

[5] S. Kadry and B. Ghazal, "Design and Assessment of Using Smartphone Application in the Classroom to Improve Students' Learning," Int. J. Eng. Pedagog., vol. 9, no. 2, pp. 17-34, 2019. https://doi.org/10.3991/ijep.v9i2.9764

[6] Y. Hendawati, S. Pratomo, Suhaedah, N. A. Lestari, T. Ridwan, and N. W. A. Majid, "The Impact of Approach Contextual Teaching and Learning Science to Improve Understand the Ability of Elementary School Student Concept," J. Phys. Conf. Ser., 2019.

[7] Ira, "Era Revolusi Industri 4.0, Saatnya Generasi Millennial Menjadi Dosen Masa Depan," Ristekdikti, 2018. [Online]. Available: http://sumberdaya.ristekdikti.go.id/index.php/2018/01/30/era-revolusi-industri-40-saatnya-generasi-millennial-menjadi-dosenmasa-depan/

[8] N. Agustina, Persaingan Industri 4.0 di ASEAN dimana Posisi Indonesia? Yogyakarta: Forbil Institute, 2018.

[9] Bakri, "Menjadi Guru Era Pendidikan 4.0," 2018. [Online]. Available: http://aceh.tribunnews.com/2018/11/27/menjadi-guru-era-pendidikan-40

[10] S. Seok, "The Aspect of E-learning," Int. J. E-Learning, vol. 7, no. 4, pp. 725-741, 2008.

[11] M. Nurtanto, H. Sofyan, M. Fawaid, and R. Rabiman, "Problem-Based Learning (PBL) in Industry 4.0: Improving Learning Quality through Character-Based Literacy Learning and Life Career Skill (LL-LCS)," Univers. J. Educ. Res., vol. 7, no. 11, pp. 2487-2494, 2019. https://doi.org/10.13189/ujer.2019.071128

[12] M. Nurtanto, D. Widjanarko, H. Sofyan, R. Rabiman, and M. B. Triyono, "Learning by Creating: Transforming Automotive Electrical Textual Material into Visual Animation as A Creative Learning Products," Int. J. Sci. Technol. Res., vol. 8, no. 10, 2019.

[13] R. C. Clark and R. E. Mayer, e-Learning and the Science of Instruction: Proven Guidelines for Consumers and Designers of Multimedia Learning, 3rd ed. San Fransisco: John Wiley \& Sons, Inc, 2011. https://doi.org/10.1002/9781118255971

[14] K. Atkinson, "Learning 4.0 is here and we should be Excited!," The Training Room Online (TTRO), 2017. [Online]. Available: https://www.ttro.com/blog/training/learning-4-0-ishere-and-we-should-be-excited/

[15] N. W. A. Majid and S. Fuada, "E-Learning for Society: A Great Potential to Implement Education for All (EFA) Movement in Indonesia," Int. J. Interact. Mob. Technol., vol. 14, no. 2, pp. 250-258, 2020. https://doi.org/10.3991/ijim.v14i02.11363

[16] M. Nurtanto and F. Rozaq, "Designing Ignition System Based Ergonomic Teaching Aid In Vocational Education: Minimizing Fatigue Factors During Practice," Int. J. Sci. Technol. Res., vol. 8, no. 11, pp. 300-303, 2019.

[17] M. Nurtanto, Parjono, Widarto, and S. D. Ramdani, "The Effect of STEM-EDP in Professional Learning on Automotive Engineering Compe-tence in Vocational High School," J. 
Educ. Gift. Young Sci., vol. 8, no. 2, pp. 633-656, 2020. https://doi.org/10.17478 ljegys.645047

[18] W. Purnomo, "Penerapan Massive Open Online Course (MOOC) berbasis Moodle sebagai Learning Management System (LMS)," in Simposium Nasional Pengembang Teknologi Pembelajaran, 2016.

[19] R. Rabiman, M. Nurtanto, and N. Kholifah, "Design And Development E-Learning System By Learning Management System (LMS) In Vocational Education," Int. J. Sci. Technol. Res., vol. 9, no. 1059-1063, 2020.

[20] D. Gamage, I. Perera, and S. Fernando, "MOOCs Lack Interactivity and Collaborativeness: Evaluating MOOC Platforms," Int. J. Eng. Pedagog., vol. 10, no. 2, pp. 94-111, 2020. https://doi.org/10.3991/ijep.v10i2.11886

[21] T. Werdiningsih, M. B. Triyono, and N. W. A. Majid, "Interactive Multimedia Learning based on Mobile Learning for Computer Assembling Subject using the Principle of Multimedia Learning (Mayer)," Int. J. Adv. Sci. Technol., vol. 28, no. 16, pp. 711-719, 2019.

[22] R. S. Pressman, Software Engineering: a practitioner's approach. New York: McGraw-Hill, 2010.

[23] M. Sudais, "Perbedaan White Box Testing dan Black Box Testing," Binus University, 2016. [Online]. Available: http://scdc.binus.ac.id/himsisfo/2016/10/perbedaan-white-box-testingdan-black-box-testing/

[24] A. Alqahtani, "Usability Testing of Google Cloud Aplications: Students' Perspective," J. Technol. Sci. Educ., vol. 9, no. 3, pp. 326-339, 2018. https://doi.org/10.3926/jotse.585

[25] J. Sauro, "5 Ways to Interpret a SUS Score," Measuring U, 2018. [Online]. Available: https://measuringu.com/interpret-sus-score/ .

[26] A. Bangor, P. T. Kortum, and J. T. Miller, "An Empirical Evaluation of the System Usability Scale," Int. J. Human-Computer Interact., vol. 24, no. 6, pp. 574-594, 2008. https://doi.org/10.1080/10447310802205776

\section{Authors}

Nuur Wachid Abdul Majid received a B.Ed. in Informatics Engineering of Education and a M.Ed. in Technology and Vocational Education, Universitas Negeri Yogyakarta, Indonesia. Now, he is an Assistant Professor in Program Studi Pendidikan Sistem dan Teknologi Informasi, Universitas Pendidikan Indonesia. His research interest include Technology and Vocational Education, Instructional Media for Learning, general education, educational psychology, and information system and analyze. Email: nuurwachid@upi.edu

Syifaul Fuada, received a B.A. in Electrical Engineering Education from Universitas Negeri Malang (UM), Indonesia, and an M.Sc. in Electrical Engineering option Microelectronics from the School of Electrical Engineering and Informatics, Institut Teknologi Bandung (ITB), Indonesia. He was with the University Center of Excellence at Microelectronics ITB from 2016-2018 as a main researcher. Now, he is with the Program Studi Sistem Telekomunikasi Universitas Pendidikan Indonesia (UPI) as a Lecturer. His research interests include analog circuit design and instrumentation, circuit simulation, engineering education, IoT, multimedia learning development and Visible Light Communication. Email: syifaulfuada@upi.edu 
Muhammad Khoirul Fajri is student at Informatics Engineering, Sekolah Tinggi Manajemen Informatika dan Komputer (STMIK) AKAKOM. He is a freelancer of front-end developer. He has skilled to develop of information system designer and make graphic designer. Email: muh.khoirulfajri.mkf@gmail.com

Muhammad Nurtanto is an assistant professor in Mechanical Engineering Education, Faculty of Teacher Training and Education, UNTIRTA, Indonesia, and is currently studying doctoral programs at the Postgraduate Program of UNY, Indonesia. His research interests discuss vocational education and training, learning in vocational schools, the vocational training, future the vocational competencies, STEM Education, Mobile Learning, and career development. He has published Scopus indexed journal papers. Affiliation: Universitas Sultan Ageng Tirtayasa, Indonesia E-mail: mnurtanto23@untirta.ac.id ORCID No: 0000-0002-6357-7152 Phone: (+62)82257810128 SCOPUS ID: 57205063285 WOS Researcher ID: J-5095- 2017. Email: mnurtanto23@untirta.ac.id

Robby Akbar is an undergraduate student in Program Studi Pendidikan Sistem dan Teknologi Informasi, Universitas Pendidikan Indonesia. His major area of interest includes systems analysis and design, and artificial intelligence with focus at online learning. He has developed secured application browser for take exam, and interactive application to facilitate students in learning SQL queries. Email: robbyakbar@upi.edu

Article submitted 2020-01-08. Resubmitted 2020-03-28. Final acceptance 2020-04-01. Final version published as submitted by the authors. 